\title{
Phytochemical analysis and in vitro screening of antifungal activity of Jatropha multifida, Euphorbia hirta, Occimum gratissimum and Mitracarpus scaber leaves extract
}

\author{
Nwofor Chioma N 1, Oyeka Christie A ${ }^{2}$, Onyenwe Nathaniel E ${ }^{3, *}$ and Fajana Aqib ${ }^{4}$ \\ ${ }^{1}$ Department of applied microbiology and brewing Nnamdi Azikiwe University Awka Nigeria. \\ ${ }^{2}$ Department of applied microbiology and brewing Nnamdi Azikiwe University Awka Nigeria. \\ ${ }^{3}$ Department of Pharmaceutical Microbiology, College of Pharmacy, Igbenedion University Okada, Benin Nigeria. \\ ${ }^{4}$ Department of Pharmacognosy, College of Pharmacy, Igbenedion University Okada, Benin Nigeria.
}

GSC Biological and Pharmaceutical Sciences, 2021, 14(03), 098-112

Publication history: Received on 08 January 2021; revised on 11 February 2021; accepted on 13 February 2021

Article DOI: https://doi.org/10.30574/gscbps.2021.14.3.0023

\begin{abstract}
The research study was to understudy the qualitative and quantitative phytochemical compounds and antifungal activity of methanolic extracts of Jatropha multifida, Euphorbia hirta, Occimum gratissimum and Mitracarpus scaber leaves against 12 species of fungi.

The 8 phytochemical compounds tested were saponin, phenol, tannin, flavonoids, steroids, terpenoid, alkaloid and glycoside. The antifungi sensitivity test was analysed by Kirby-bauer disc diffusion method. The minimum inhibitory concentration (MIC) and minimum fungicidal concentration (MFC) was analysed by broth tube dilution method followed by subculturing the relative samples. The plant extracts were prepared in the concentration range of 6.25 , $12.5,25,50,100$ and $200 \mathrm{mg} / \mathrm{ml}$. The antifungal sensitivity test showed that Jatropha multifida (200mg/ml) was weakly effective against Fusarium solani and resistant against others. Occimum gratissimum, Euphorbia hirta and Mitracarpus scaber at $(200 \mathrm{mg} / \mathrm{ml})$ respectively was highly effective on most of the fungi species tested with zone of inhibition of 10 $20 \mathrm{~mm}$. Jatropha multifida had MIC and MFC $(>200 \mathrm{mg} / \mathrm{ml})$, Occimum gratissimum had MIC and MFC (100 and $>100 \mathrm{mg} / \mathrm{ml}$ ), Euphorbia hirta (25-200 and $50->200 \mathrm{mg} / \mathrm{ml}$ ) and Mitracarpus scaber had (25 - 100 and 50-200mg/ml) on most test isolates respectively. Investigations showed, Mitracarpus scaber were highly effective, followed by Euphorbia hirta, Occimum gratissimum and Jatropha multifida on the test organisms and could be attributed to the presence of phytochemical compounds and as such can be harnessed and used as a source of alternative medicine especially in the tropics like the South-eastern Nigeria.
\end{abstract}

Keywords: Phytochemicals; Jatropha multifida; Euphorbia hirta; Occimum gratissimum and Mitracarpus scaber.

\section{Introduction}

The use of medicinal plants in the treatment of diseases are of immense importance in the health of people. It is closely linked with conventional medicine as it is being used now in curing both emerging and re-emerging infections [1]. Herbs derived from different parts (leaves, roots, seeds, berries, bark or flowers) of plant extracts have gone a long way in treating a wide range of clinical diseases [2]. These plant parts possess certain chemicals known as primary and secondary metabolites.The primary metabolites includes amino acids, sugar, purines and primidines while the secondary metabolites incudes alkaloids, glycosides, phenols, terpenoids. The distribution and concentration of these chemicals differ from one plant to another and from one plant part to another. Chemical compounds such as alkaloids

\footnotetext{
* Corresponding author: Onyenwe Nathaniel Ejikeme

Department of Pharmaceutical Microbiology, College of Pharmacy, Igbenedion University Okada, Benin Nigeria. 
and glycosides are known to be poisonous if present in large quantities but can be useful and harmless if used in smaller quantity [3]. About three quarter of the world today relie on plants and their extracts for their healthcare [4].These extracts are now known as a potentially source for the development of chemotherapeutic agents [5].

\subsection{Mitracarpus scaber}

This plant belongs to the family Rubiaceae and it is popularly known as the madder family. It belongs to the Gentianales order which is now called Rubiales order. This family consists of approximately 500 genera and about 6,000 species which can be found all over the world. Some of them can be seen as tropical trees and shrubs (erect, struggling or twining) while some are found as herbs (erect or decumbent). Mitracarpus Scaber is a herb that is about $30 \mathrm{~cm}$ in height or less and possess rough leaves. In Nigeria, different tribes have different names for it. The Igbos' call it Obuobwa, Hausas' call it Gududal while the Yorubas' call it Irawo [6]. Its leaves extract can be used in treating a lot of diseases traditionally like headache, toothaches, hepatic diseases, veneral diseases as well as leprosy. It is also believed to possess both antibacterial and antifungal activities [7]. In Nigeria, its leaf extract have been used in treatment of some skin diseases like, eczema, ringworm, lice, craw-craw, lice. It can be used in dressing cuts, ulcers and wounds [6]. Due to the immense importance of this plant a lot of scientific studies have been carried out to determine the antibiotic effectiveness of its leaf extracts.

In a study by [7], syrup were formulated from crude extracts of Mitracapus scaber "zucc". The antimicrobial activity of the syrup was analysed using agar plates containing these extracts at different concentrations ranging from $25 \mathrm{mg} / \mathrm{ml}$ and $300 \mathrm{mg} / \mathrm{ml}$. This preparation was used to determine the minimum inhibitory concentration against a fungal organism namely Candida albicans at $37^{\circ} \mathrm{C}$. At the end of the experiment results showed that Candida albicans were inhibited by the formulation at a minimum inhibitory concentration of $75 \mathrm{mg} / \mathrm{ml}$. [8] also evaluated the antimycotic activity of crude methanolic extracts of Mitracarpus scaber on Candida albicans and Trichophyton mentagrophytes. In his work, $20 \mathrm{mg} / \mathrm{ml}$ solution of methanol crude extract was prepared as against standardized solution of Nystatin and Griseofulvin prepared from conventional products. $0.05 \mathrm{ml}$ of each preparations were added to sterilized sabouraud dextrose agar containing chloramphenicol, after which the test organisms were inoculated onto the agar slants and then incubated at $37^{\circ} \mathrm{C}$. Results showed that Mitracarpus scaber inhibited the growth of both organism at $4 \mathrm{mg} / \mathrm{ml}$ while Nystatin did not inhibit the growth of Candida albicans but inhibited the growth of T.mentagrophytes at 7mg/ml. [9], surveyed the efficacy of two commonly used antifungal herbs in Nigeria against clinical isolates of fungi. In their work Mitracarpus scaber and Occimum gratissmum were used to test its antifungal activities against fungal isolates (moulds and yeast) recovered from subjects in a community. The test isolates were from skin/scalp scrapings, Candida albicans, sputum, urine, endocervical swab, groin, mouth thrush and palm. In-vitro antifungal activity of the ethanol extract of Mitracarpus scaber $\left(50 \mathrm{\mu gml}^{-1}\right)$ showed that the clinical isolates were sensitive to the herbal extracts but were more

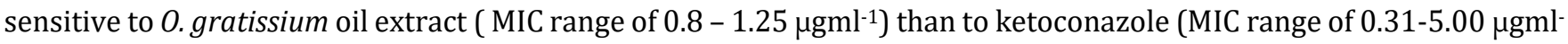
1). [10] worked on the action of miscamates soap in the treatment of ringworm. In their research a soap was produced by combining plant oils for the treatment of skin infections (Mitracarpus scaber, Cassia alata and Mareya micrantha). This soap was subjected to an in-vitro test on Trichophyton mentagrophytes and clinical trials on infected patients. Studies from this work showed that the soap is active in-vitro on T. mentagrophytes and its application provides total cure for ringworm.

\subsection{Jatropha multifida}

The genus name of this plant Jatropha is a greek word jatros (doctor) and trophie (food) which means medicinal uses [11]. This plant belongs to the family Euphorbiaceae. It can be seen as a shrub or a tree that is drought resistant. It can be found in the wild or semi-cultivated areas in central and South America, Africa, India and South East Asia [12]. Different parts of the Jatropha (seeds, leaves, bark etc) are known to be of great importance in traditional medicine and for veterinary purposes [13]. On the other hand Jatropha is a non edible oil seed plant, whole extracts from different parts is known to be toxic. This toxic effect of the extracts is as a result of the presence of a toxic ingregient called phorbol ester which is known to contain moluscicidal, Piscicidal, insecticidal, rodenticidal, anti-microbial and cytotoxic properties. Its adverse effects on animals including rats, poultry and ruminants are also well established [14]. A study by [15] showed that Jatropha multifida latex (whole plant) can be used to cure wounds but toxic when they surveyed the ethanomedical of plants used by local society in Poncokusumo district Malang, East Java Province, Indonesia.Wongsatit [16], observed that the watery sap of Jatropha multifida obtained by decoction can be used to treat stomach pain when he surveyed the utilization of medicinal plants used by herbalists in Khok Pho District, Pattani Province (Thailand). [5] in their work screened the antibacterial and antifungal activities of Jatropha multifida (Ogege) sap against some pathogens which include Pseudomona aeruginosa, Klebsiella pneumonia, Staphylococcus aureus, Escherichia coli, Bacillus subtilis, Salmonella typhi and Candida sp. usuing agar well diffusion and broth dilution methods to determine minimum inhibitory concentration (MIC) and minimum bactericidal concentration (MBC) at concentration 
of $1050 \mathrm{mg} / \mathrm{ml}$ to $2 \mathrm{mg} / \mathrm{ml}$ (by two fold dilution using sterile distilled water, results showed that all the organisms were susceptible to the sap. [17] studied the antimicrobial activity of Jatropha multifida extracts and chromatographic fractions against microorganisms responsible for sexually transmitted infections. In their research, hexane, ethyl acetate and methanol extracts of the plant and chromatographic fractions were screened against seven pathogenic organisms comprising gram positive and gram negative bacteria and fungi. The results showed potent antimicrobial activity against the isolates.

\subsection{Occimum gratissimum}

This is a shrub that belongs to the family Lamiaceae. It is popularly known as scent leaf or dove basil. It is usually found in tropical countries. Although Africa and Asia are the two continents where most variants of the plant exists [18]. In Nigeria, different tribes have different names for it. In Igbo it is called Ncho-anwu, Ahuji, in Yoruba it is called Efinrin, in Hausa it is called Daidoya while Edo people calls it Aramogbo [19]. Occimum gratissimum has been known to possess an antibacterial and antifungal properties and as a result has been of great importance to the medical field [20]. It has been proven that 0 . gratissimum is very useful in the medication for people living with Human Immunodeficiency virus (HIV) and Acquired Immuno Deficiency Syndrome Virus (AIDS) [21]. It is also useful in the treatment of gonorrheal infection, vaginitis, vaginal douches for metritis and mental sickness [21].

Occimum gratissimum have also been known to be active against some pathogenic bacteria like Escherichia coli, klebsiella pneumonia, Pseudomonas aerugnosa, Proteus vulgaris, Streptococcus vivadians [19] and some fungi like Trichophyton rubrum, Crytococcus neoformans, T. mentagrophytes,Candida albicans [20]. Traditionally it is used in the treatment of ailments like urinary tract, wound, skin and gastrointestinal infections [22]. The plant is an erect small plumb with many barnacles usually not more than $1 \mathrm{~m}$ high [22]. Phytochemical evaluation of Occimum gratissimum reveals that it is rich in alkaloid, tannis, phytates, flavonoids and Oligosaccharides [23]. Around the coastal area of Nigeria, this plant is used in the treatment of epilepsy [24].

Also, [20] studied the effects of Occimum gratissimum leaves on common dermatophytes and Malassezia furfur in Rivers state, Nigeria using well-in-agar diffusion technique with different concentrations of ethanolic extracts. Its isolates were gotten from scalp, skin, toes and feet. Results showed a significant inhibitory effect of Occimum gratissimum at five different concentrations of $250 \mathrm{mg} / \mathrm{ml}, 200 \mathrm{mg} / \mathrm{ml}, 150 \mathrm{mg} / \mathrm{ml}, 100 \mathrm{mg} / \mathrm{ml}$ and $50 \mathrm{mg} / \mathrm{ml}$ used. [25] surveyed the antifungal activity of Occimum gratissium towards dermatophytes caused by Microsporum canis, M.gypseum, Trichophyton rubrum and T. mentagrophytes. Occimum gratissimum extracts (hexane, chloroform fractions, the essential oil and eugenol) were investigated using agar dilution method against their dematophytes. Results showed that hexane and eugenol were the most active although hexane inhibited the growth of all isolates $100 \%$ at the concentration of $125 \mathrm{ml}^{-1}$. [22] justified the use of Occimum gratissium as a herbal medicine when they evaluated its interaction with disc antibiotics. This was achieved by testing the antibacterial and antifungal properties of the ethanolic extract of the leaves of Occimum gratissimum as against four clinical isolates namely Escherichia coli, Proteus mirabilis, Staphylococcus aureus, Pseudomonas aeruginosa and Candida albicans. Also a typed bacterium of Escherichia Coli (ATCC 11775) and another typed fungal strain of Candida albicans (ATCC 90028) were included. The research also went further to verify if the concomitant administration of conventional antibiotics with Occimum gratissimum will affect its activity negatively since it is normally eaten as food (spice). This experiment were carried out using agar diffusion method to test the in-vitro activity of this plant extract and some of the conventional disc antibiotics used are Ciprofloxacin, Septrin, Streptomycin, Ampicillin, Nysatin and Ketoconazole. Results were positive although there were varying in-vitro activities against all the isolates used. [24] in his work, studied the antibacterial properties of Occimum gratissimum against some selected entero-bacteriacea. Water and ethanol were used for the extraction of the active constituents of the plant and results revealed that water extracts of the plant was not as active as the ethanolic extracts against the tested organisms.

\subsection{Euphorbia hirta (Leaves)}

Euphorbia hirta (linn) belongs to the family Euphorbiaceae. It is a small annual plant commonly found in tropical countries. Its height is usually about $40 \mathrm{~cm}$. Its stem is slender and often reddish in colour. Its young ones are covered with a yellowish bristly hairs. Its leaves are oppositely arranged and lanceolate [26]. When plucked its stem and leaves produces whitish or milky juice [26]. Its leaves are known to treat dysentery, cough, asthma, worms and vomiting. The white latex is used as eye drops to cure conjunctivitis, it is applied on swellings, piles and boils [27]. Its main components are flavonoids, terpenoids and phenols [28]. So many antimicrobial works have been carried out using extracts from different parts of Euphobia hirta plant. A work by [29] showed the antibacterial activity of Euphorbia hirta extracts against some clinically important bacterial species. Ethanol and petroleum ether extracts of Euphorbia hirta were prepared at different concentrations $(25 \mu \mathrm{g} / \mathrm{ml}, 50 \mu \mathrm{g} / \mathrm{ml}, 75 \mu \mathrm{g} / \mathrm{ml}$ and $100 \mu \mathrm{g} / \mathrm{ml})$ and its antibacterial activity was tested using cup-plate method. Results showed that the ethanol extracts have potentially deleterious effects on the 
microorganisms. [30] in his work, assessed extracts of Euphorbia hirta L. Leaf, flower, stem and root for their antibacterial and antifungal activity and brine shrimp lethality against some medically important bacteria and yeasts using the agar disc diffusion method. Results showed that leaves extract inhibited the growth of all tested organisms including the yeast (Candida albicans) with large zone of inhibition.

[31] in their work extracted and tested the antimicrobial activity of alkaloids of Euphorbia hirta against four bacteria (Escherichia Coli, Pseudomonas aeruginosa, Proteus mirabilis and Staphylococcus aureus) and four fungi (Aspergillus flavus, Aspergillus niger, Candida albicans and Trichophyton mentagrophytes). This was achieved by using the disc diffusion assay. Results showed that all micro organisms were sensitive against all the tested extracts from different parts (leaf, stem, root and fruits) of Euphorbia hirta. [32] carried out a review on plants used to treat skin diseases, amongst Euphorbia species, of all the species Euphorbia hirta showed to have the highest antioxidant activity.

\section{Material and methods}

\subsection{Test isolates}

The fungal strains were isolated from cattle skin samples using cultural methods on sabouraud dextrose agar plates and then identified by DNA sequencing using the BigDye Terminator kit on a 3510 ABI sequencer by Inqaba Biotechnological, Pretoria South Africa. The fungal strains were Penicillum citrinum (MH990629), Aspergillus fumigatus (MK4610, Aspergillus welwitschiae (MG576117), Aspergillus aculeatus (MK461093), Aspergillus flavus (Mk 299130), Fusarium succisae (Mk 418691), Curvularia kusanol (MG975624), Cladosporium tenuissimum (MK 357638), Pestalotiopsis microspora (MK 224482), Fusarium solani (MH517359), Fusarium lichenicola (KH921661) and Absidia spp.

\subsection{Collection and identification of plant materials}

Fresh leaves of Mitracarpus scaber, Jatropha multifida, Occimum gratissimum and Euphorbia hirta plants were collected from the Federal research institute Ibadan Nigeria.They were identified and authenticated at the department of Botany Igbenedion University Okada, Edo State by a taxonomist. To prepare the plant material (leaves) for analysis, the leaves were washed and rinsed with distilled water, dried initially at room temperature and finally in a thermostatically controlled hot air oven at $40{ }^{\circ} \mathrm{C}$ until constant weight is maintained [33].

The leaves were ground into fine powder in an electric blender.The powdered materials were stored in screw capped bottles and kept in a refrigerator at $4{ }^{\circ} \mathrm{C}$ until required for use [34].

\subsection{Extraction of active components from plant materials}

The active principle of the plant (leaves) were extracted, using soxhlet extractor and rotary evaporator in a microbiology laboratory of Igbenedion University Okada, Edo State. One kilogram of the powered materials, was extracted in $250 \mathrm{ml}$ of 95\% methanol to extract the active principle using soxhlet apparatus as described [33 -35]. The crude extract was allowed to evapourate to dryness using rotary evaporator [35].

\subsection{Phytochemical screening of the plant leaves}

\subsubsection{Test for saponins}

$3 \mathrm{~g}$ of plant powder was boiled in $10 \mathrm{ml}$ of water, warmed and filtered. $2 \mathrm{ml}$ of filtrate was mixed with $5 \mathrm{ml}$ of distilled water and then warmed on the water shaken vigorously for a stable persistent froth. The presence of frothing which lasted for 3 - 5 minutes indicated the presence of saponins [36-37].

\subsubsection{Test for phenolic compounds}

$5 \mathrm{~g}$ of the sample was also boiled with $25 \mathrm{ml}$ of methanol, then warmed on water bath and filtered. $2 \mathrm{ml}$ of the filtrate was mixed into $2 \mathrm{ml}$ of $1 \%$ ferric chloride solution. The formation of brownish- green precipitate was taken for the presence of condensed tannin while bluish-black precipitate was taken for the presence of hydrolysable tannin [36-37].

\subsubsection{Test for flavonoids}

Another $2 \mathrm{ml}$ of filtrate obtained from methanol extract of the plant samples was added to $2 \mathrm{ml}$ dilute ammonia solution.The appearance of a yellow colour was taken for the presence of flavonoids [36-37]. 


\subsubsection{Test for steriods}

$2 \mathrm{ml}$ of acetic anhydride was added to $0.5 \mathrm{~g}$ methanol extract of sample in the presence of $2 \mathrm{ml} \mathrm{H}_{2} \mathrm{SO}_{4}$. Colour changes from violet to blue or green indicates the presence of steroids [36-37].

\subsubsection{Test for terpenoids}

$0.5 \mathrm{~g}$ of methanol extract was mixed in $2 \mathrm{ml}$ of chloroform. $1 \mathrm{ml}$ of concentrated $\mathrm{H}_{2} \mathrm{SO}_{4}$ was carefully added to form a lower layer. A reddish brown coloration at interface was taken for the presence of steroids [36-37].

\subsubsection{Test for alkaloids}

A quantity of $0.1 \mathrm{~g}$ of the ground samples were boiled with $5 \mathrm{ml}$ of $2 \%$ hydrochloric acid on a steam bath. This was filtered and $1 \mathrm{ml}$ portion of the filtrate reacted with 2 drops of the following reagents [38].

- Wagners reagent (Iodine in potassium iodide solution), and observed for reddish brown precipitate.

- Meyers reagent (potassium mercuric iodide solution), and observed for creamy coloured precipitate.

\subsubsection{Test for phlobatannin}

$0.5 \mathrm{~g}$ of methanol extract was added $3 \mathrm{ml}$ of $1 \% \mathrm{HCL}$ and water on water bath at $90{ }^{\circ} \mathrm{C}$ for 15 minutes. The formation of red residue at the base of test-tube was taken for the presence of tannin [36-37].

\subsubsection{Test for cardiac glycosides (Keller-Killani)}

The presence of cardiac glycoside (five membered lactone, characteristics of cardiac glycoside) was tested by adding of $1 \mathrm{ml}$ methanol extract of the plant samples with $1 \mathrm{ml}$ of kedde's reagent and $1 \mathrm{ml}$ of dilute sodium hydroxide, the formation of violet colour was taken as presence of cardiac glycosides [36-37].

\subsection{Quantitative analysis of plant leaves}

\subsubsection{Alkaloid determination}

The plant leave extracts (1mg) was dissolved in dimethyl Sulphoxide (DMSO), $1 \mathrm{ml}$ of $2 \mathrm{~N} \mathrm{Hcl}$ was added and filtered. $1 \mathrm{ml}$ of the filtrate was mixed with $1 \mathrm{ml}$ of bromocresol green solution (BCG), $2 \mathrm{ml}$ of chloroform and was later diluted with $6 \mathrm{ml}$ of water.

A standard solution was also prepared in the same manner as described earlier. The absorbance of for test and standard solution was determined against the reagent blank at 470nm wavelength using the UV spectrophotometer [39].

\subsubsection{Phenol determination}

The phenolic content of the plant leaf were determined using Folin-Denis reagent. $10 \mathrm{ml}$ of the sample filterate was mixed with $1 \mathrm{ml}$ of Folin-Denis reagent and $1 \mathrm{ml}$ of sodium carbonate. The solution was kept at room temperature for 5minutes.

For standard solution gallic acid was prepared (5g of gallic acid was dissolved in $100 \mathrm{ml}$ of water and mixed with $1 \mathrm{ml}$ of sodium carbonate). This was used to measure absorbance for the test at $750 \mathrm{~nm}$ using spectrophotometer [39].

\subsubsection{Glycoside determination}

1gram of sample was solubilized in $50 \mathrm{ml}$ of water and filtered. $1 \mathrm{ml}$ of the filtrate was mixed with $2 \mathrm{ml}$ of dinitricsaliculic acid $(10 \mathrm{~g}$ of sodium hydroxide was dissolved in $250 \mathrm{ml}$ of water, $60 \mathrm{ml}$ of this solution was then mixed with $2 \mathrm{grams}$ of saliculic acid) and allowed to stand for some minutes.

For standard solution, glucose solution was prepared and used to determine total glycosidic content for test at $540 \mathrm{~nm}$ wavelength [39].

\subsubsection{Saponin determination}

$0.5 \mathrm{gram}$ of sample was dispensed in $50 \%$ methanol in a conical flask. This was heated for 3 hours after which the solution was filtered. $1 \mathrm{ml}$ of filterate was mixed with $5 \mathrm{ml}$ of magnesium carbonate and $1 \mathrm{ml}$ of $5 \%$ ferric chloride. The absorbance of saponin content was determined using spectrophotometer at wavelength at 380nm [39]. 


\subsubsection{Flavonoid determination}

1 gram of sample was weighed and dissolved in $50 \mathrm{ml}$ of $50 \%$ methanol. $1 \mathrm{ml}$ of extract was mixed with 200 microliter sodium nitrate $(100 \mathrm{ml}, 5 \%), 200$ microliter of $10 \%$ aluminum chloride and allowed to stand for 5 mins after which $1 \mathrm{ml}$ sodium hydroxide was added and allowed to stand for 10 minutes. The absorbance was of the test was measured using spectrophotometer at 510 $\mathrm{nm}[40]$.

\subsubsection{Tannin determination}

$1 \mathrm{ml}$ of sample filtrate was mixed with $0.5 \mathrm{ml}$ of Follin-Dennis reagent and $5 \mathrm{ml}$ of $5 \%$ sodium carbonate. This was kept undisturbed for about 30mins.

The standard solution of $1 \mathrm{mg} / \mathrm{ml}$ tannin was prepared by dissolving $100 \mathrm{mg}$ stock solution of tannic acid in water.1ml of tannic acid was measured and mixed with $0.5 \mathrm{ml}$ of Folin -Denis reagent and $5 \mathrm{ml}$ sodium carbonate solution. The tannin content for the test was measured by reading at $760 \mathrm{~nm}$ against blank reagent using spectrophotometer [41].

\subsubsection{Steriod determination}

0.5 gram of sample was weighed and mixed with $50 \mathrm{ml}$ of $50 \%$ methanol which was heated for 30 minutes and then filtered. The filterate was mixed with $2 \mathrm{ml}$ of 2 mole solution of sulphuric acid, $2 \mathrm{ml}$ of $10 \%$ ferric chloride and $0.5 \mathrm{ml}$ of ferric cyanide. The absorbance was read at 750nm wavelength using UV spectrophotometer [39].

\subsection{Dillution of plant extracts}

Crude extracts of the plant (leaves) were allowed to evapourate to dryness. The solvent used for all plant extracts were dissolve in 99\% dimethyl sulfoxide (DMSO). Two grams of the dried extract were dissolved in 10ml 99\% dimethlyl sulphoxide (DMSO) to obtain the stock of $200 \mathrm{mg} / \mathrm{ml}$. Briefly 5 two-fold extract dilution were prepared in $5 \mathrm{ml}$ to obtain the different concentrations of $100 \mathrm{mg} / \mathrm{ml}, 50 \mathrm{mg} / \mathrm{ml}, 25 \mathrm{mg} / \mathrm{ml}, 12.5 \mathrm{mg} / \mathrm{ml}$ and $6.25 \mathrm{mg} / \mathrm{ml}$. These were applied on already prepared discs.

\subsection{Antifungal susceptibility testing of extracts}

Antifungal susceptibility test were carried out on 12 fungal strains using the crude extracts of the plant leaves. This was carried out, using disc diffusion method. In this method, $1 \mathrm{ml}$ of the test isolate in sabouraud dextrose broth (SDB) was diluted in $9 \mathrm{ml}$ of distilled water. $0.2 \mathrm{ml}$ of the dilution was spread evenly on the surface of the solidified sabouraud dextrose agar (SDA) plates, using a sterile bent glass rod spreader (Hockey stick) before introducing the discs.

\subsection{Preparation of disc}

Sterile paper discs (made of Whatman No.1 filter paper) measuring about $6 \mathrm{~mm}$ was used to impregnate about $20 \mu \mathrm{l}$ of the different dilutions $(200 \mathrm{mg} / \mathrm{ml}, 100 \mathrm{mg} / \mathrm{ml}, 50 \mathrm{mg} / \mathrm{ml}, 25 \mathrm{mg} / \mathrm{ml}, 12.5 \mathrm{mg} / \mathrm{ml}$ and $6.25 \mathrm{mg} / \mathrm{ml})$ of the plant extract and then air dried. This discs were transferred onto the solidified sabouraud dextrose agar media evenly spread with the isolate. $20 \mu \mathrm{l}$ of $99 \%$ DMSO was also impregnated on a separate disc and delivered as a control and labeled accordingly. This was inoculated on triplicate. The discs were kept on the bench for 40minutes for pre-diffusion of the extract. After diffusion, the discs were aseptically introduced on the surface of the medium with the aid of a sterile forceps and allowed for 10-15 mins, before incubating at $35 \circ \mathrm{C}$ for 72 hours and examined for fungal growth inhibition. The diameter zone of growth inhibition on the different plates was measured in millimeters, using a transparent metric rule.

\subsection{Determination of the minimum inhibitory concentration (mic) using tube dilution method}

The tube dilution method of broth was used to determine the MIC of the test extract, using two fold serial broth dilution method. The selected plant leaves extract were Occimum gratissimum, Euphorbia hirta, Jatropha multifida and Mitracarpus scaber.

A double strength broth of sabouraud dextrose broth with extract was prepared (5ml of 99\% DMSO was used to dissolve $2 \mathrm{~g}$ of the extract initially and then raised to $10 \mathrm{ml}$ using $5 \mathrm{ml}$ of double strength sabouraud dextrose broth). This was diluted serially by introducing $5 \mathrm{ml}$ of the stock aliquot into $5 \mathrm{ml}$ of single strength broth to obtain $100 \mathrm{mg} / \mathrm{ml}$. Similarly dilutions up to $10^{-4}$ was carried out to obtain $50 \mathrm{mg} / \mathrm{ml}, 25 \mathrm{mg} / \mathrm{ml}, 12.5 \mathrm{mg} / \mathrm{ml}$ and $6.25 \mathrm{mg} / \mathrm{ml}$ respectively. The serially diluted test extracts were then inoculated each with $0.2 \mathrm{ml}$ of $10^{-2}$ dilutions of an overnight broth culture of the test isolates. All tubes were incubated for 72 hours and later inoculated onto sterile sabouraud dextrose agar plates and incubated. The least drug concentration that showed least growth was taken as the minimum inhibitory concentration 
(MIC) for the particular plant extract while absence of growth indicates a fungicidal concentration; hence the Minimum Fungicidal Concentration (MFC) as described by Clinical Laboratory Standards Institute, CLSI [42].

\section{Results and discussion}

Table 1 Qualitative phytochemical analysis

\begin{tabular}{|c|c|c|c|c|}
\hline Test & Plants & & & \\
\hline & $\begin{array}{l}\text { Occimum } \\
\text { gratissium }\end{array}$ & Euphorbia hirta & $\begin{array}{l}\text { Mitracarpus } \\
\text { scaber }\end{array}$ & $\begin{array}{l}\text { Jatropha } \\
\text { multifida }\end{array}$ \\
\hline Saponin & + & + & + & ++ \\
\hline Phenol & + & - & - & + \\
\hline Tannin & - & - & ++ & + \\
\hline Flavonoids & + & + & + & + \\
\hline Steriods & + & ++ & ++ & ++ \\
\hline Terpenoids & ++ & ++ & +++ & + \\
\hline \multicolumn{5}{|l|}{ Alkaloids } \\
\hline Wagner & - & + & ++ & + \\
\hline Mayer & + & - & + & - \\
\hline Glycoside & ++ & ++ & +++ & + \\
\hline
\end{tabular}

Key: (+) present, (-) absent and (++) abundance

Table 2 Quantitative phytochemical analysis of the plant leaves.

\begin{tabular}{|l|l|l|l|l|}
\hline Test & Plants (mg/100g) & $\mathbf{( m g / 1 0 0 g ) ~}$ & $\mathbf{( m g / 1 0 0 g )}$ & $\mathbf{( m g / 1 0 0 g ) ~}$ \\
\hline & $\begin{array}{l}\text { Occimum } \\
\text { gratissium }\end{array}$ & Euphorbia hirta & Mitracarpus scaber & $\begin{array}{l}\text { Jatropha } \\
\text { multifida }\end{array}$ \\
\hline Saponin & 27.94 & 27.94 & 27.84 & 27.9 \\
\hline Phenol & 0.0085 & 0.0023 & 0.0127 & 0.0023 \\
\hline Tannin & 0.0262 & 0.1606 & 0.054 & 0.030 \\
\hline Flavonoids & -2.04 & -6.68 & -0.310 & -2.030 \\
\hline Steriods & 35.7 & 35.86 & 35.7 & 35.9 \\
\hline Alkaloids & 0.6122 & 0.3502 & 0.369 & 0.383 \\
\hline Glycoside & 0.232 & 0.744 & 0.660 & 0.510 \\
\hline
\end{tabular}


Table 3 Antifungal susceptibility pattern of 12 non-dermatophyte molds isolated from this study against the four selected methanolic extracts of the plant leaves.

\begin{tabular}{|c|c|c|c|c|c|c|c|c|c|c|c|c|c|c|c|c|c|c|c|c|c|c|c|c|}
\hline \multirow{2}{*}{$\begin{array}{r}\text { Isolates } \\
\mathrm{mg} / \mathrm{ml}\end{array}$} & \multicolumn{6}{|c|}{ Jatropha multifida } & \multicolumn{6}{|c|}{ Occimum gratissium } & \multicolumn{6}{|c|}{ Euphobia hirta } & \multicolumn{6}{|c|}{ Mitracarpus scaber } \\
\hline & 200 & 100 & 50 & 25 & 12.5 & 6.25 & 200 & 100 & 50 & 25 & 12.5 & 6.25 & 200 & 100 & 50 & 25 & 12.5 & 6.25 & 200 & 100 & 50 & 25 & 12.5 & 6.25 \\
\hline $\begin{array}{l}\text { Fusarium } \\
\text { solani }\end{array}$ & $15^{\mathrm{RM}}$ & $\mathrm{R}$ & $\mathrm{R}$ & $\mathrm{R}$ & $\mathrm{R}$ & $\mathrm{R}$ & $\mathrm{R}$ & $\mathrm{R}$ & $\mathrm{R}$ & $\mathrm{R}$ & $\mathrm{R}$ & $\mathrm{R}$ & 10 & $\mathrm{R}$ & $\mathrm{R}$ & $\mathrm{R}$ & $\mathrm{R}$ & $\mathrm{R}$ & $\mathrm{R}$ & $\mathrm{R}$ & $\mathrm{R}$ & $\mathrm{R}$ & $\mathrm{R}$ & $\mathrm{R}$ \\
\hline $\begin{array}{l}\text { Fusarium } \\
\text { succisae }\end{array}$ & $\mathrm{R}$ & $\mathrm{R}$ & $\mathrm{R}$ & $\mathrm{R}$ & $\mathrm{R}$ & $\mathrm{R}$ & $\mathrm{R}$ & $\mathrm{R}$ & $\mathrm{R}$ & $\mathrm{R}$ & $\mathrm{R}$ & $\mathrm{R}$ & 10 & $\mathrm{R}$ & $\mathrm{R}$ & $\mathrm{R}$ & $\mathrm{R}$ & $\mathrm{R}$ & $\mathrm{R}$ & $\mathrm{R}$ & $\mathrm{R}$ & $\mathrm{R}$ & $\mathrm{R}$ & $\mathrm{R}$ \\
\hline $\begin{array}{l}\text { Fusarium } \\
\text { lichenicola }\end{array}$ & $\mathrm{R}$ & $\mathrm{R}$ & $\mathrm{R}$ & $\mathrm{R}$ & $\mathrm{R}$ & $\mathrm{R}$ & 5 & $\mathrm{R}$ & $\mathrm{R}$ & $\mathrm{R}$ & $\mathrm{R}$ & $\mathrm{R}$ & $\mathrm{R}$ & $\mathrm{R}$ & $\mathrm{R}$ & $\mathrm{R}$ & $\mathrm{R}$ & $\mathrm{R}$ & 10 & $\mathrm{R}$ & $\mathrm{R}$ & $\mathrm{R}$ & $\mathrm{R}$ & $\mathrm{R}$ \\
\hline $\begin{array}{l}\text { Aspergillus } \\
\text { flavus }\end{array}$ & $\mathrm{R}$ & $\mathrm{R}$ & $\mathrm{R}$ & $\mathrm{R}$ & $\mathrm{R}$ & $\mathrm{R}$ & 20 & $\mathrm{R}$ & $\mathrm{R}$ & $\mathrm{R}$ & $\mathrm{R}$ & $\mathrm{R}$ & 15 & $\mathrm{R}$ & $\mathrm{R}$ & $\mathrm{R}$ & $\mathrm{R}$ & $\mathrm{R}$ & 10 & 10 & $\mathrm{R}$ & $\mathrm{R}$ & $\mathrm{R}$ & $\mathrm{R}$ \\
\hline $\begin{array}{l}\text { Aspergillus } \\
\text { welwitschiae }\end{array}$ & $\mathrm{R}$ & $\mathrm{R}$ & $\mathrm{R}$ & $\mathrm{R}$ & $\mathrm{R}$ & $\mathrm{R}$ & 10 & $\mathrm{R}$ & $\mathrm{R}$ & $\mathrm{R}$ & $\mathrm{R}$ & $\mathrm{R}$ & 16 & $\mathrm{R}$ & $\mathrm{R}$ & $\mathrm{R}$ & $\mathrm{R}$ & $\mathrm{R}$ & 15 & 10 & $\mathrm{R}$ & $\mathrm{R}$ & $\mathrm{R}$ & $\mathrm{R}$ \\
\hline $\begin{array}{l}\text { Aspergillus } \\
\text { fumigatus }\end{array}$ & $\mathrm{R}$ & $\mathrm{R}$ & $\mathrm{R}$ & $\mathrm{R}$ & $\mathrm{R}$ & $\mathrm{R}$ & 15 & 10 & 10 & 10 & $\mathrm{R}$ & $\mathrm{R}$ & 10 & $\mathrm{R}$ & $\mathrm{R}$ & $\mathrm{R}$ & $\mathrm{R}$ & $\mathrm{R}$ & 15 & 10 & 5 & $\mathrm{R}$ & $\mathrm{R}$ & $\mathrm{R}$ \\
\hline $\begin{array}{l}\text { Aspergillus } \\
\text { aculeatus }\end{array}$ & $\mathrm{R}$ & $\mathrm{R}$ & $\mathrm{R}$ & $\mathrm{R}$ & $\mathrm{R}$ & $\mathrm{R}$ & 15 & 10 & $\mathrm{R}$ & $\mathrm{R}$ & $\mathrm{R}$ & $\mathrm{R}$ & $\mathrm{R}$ & $\mathrm{R}$ & $\mathrm{R}$ & $\mathrm{R}$ & $\mathrm{R}$ & $\mathrm{R}$ & 12 & $\mathrm{R}$ & $\mathrm{R}$ & $\mathrm{R}$ & $\mathrm{R}$ & $\mathrm{R}$ \\
\hline $\begin{array}{l}\text { Clasdosporium } \\
\text { tenuissimum }\end{array}$ & $\mathrm{R}$ & $\mathrm{R}$ & $\mathrm{R}$ & $\mathrm{R}$ & $\mathrm{R}$ & $\mathrm{R}$ & $\mathrm{R}$ & $\mathrm{R}$ & $\mathrm{R}$ & $\mathrm{R}$ & $\mathrm{R}$ & $\mathrm{R}$ & 15 & $\mathrm{R}$ & $\mathrm{R}$ & $\mathrm{R}$ & $\mathrm{R}$ & $\mathrm{R}$ & 15 & $\mathrm{R}$ & $\mathrm{R}$ & $\mathrm{R}$ & $\mathrm{R}$ & $\mathrm{R}$ \\
\hline $\begin{array}{l}\text { Curvularia } \\
\text { kusanol }\end{array}$ & $\mathrm{R}$ & $\mathrm{R}$ & $\mathrm{R}$ & $\mathrm{R}$ & $\mathrm{R}$ & $\mathrm{R}$ & 20 & 20 & 10 & 10 & $\mathrm{R}$ & $\mathrm{R}$ & 10 & $\mathrm{R}$ & $\mathrm{R}$ & $\mathrm{R}$ & $\mathrm{R}$ & $\mathrm{R}$ & 10 & $\mathrm{R}$ & $\mathrm{R}$ & $\mathrm{R}$ & $\mathrm{R}$ & $\mathrm{R}$ \\
\hline $\begin{array}{l}\text { Pestaloptiosis } \\
\text { microspora }\end{array}$ & $\mathrm{R}$ & $\mathrm{R}$ & $\mathrm{R}$ & $\mathrm{R}$ & $\mathrm{R}$ & $\mathrm{R}$ & $\mathrm{R}$ & $\mathrm{R}$ & $\mathrm{R}$ & $\mathrm{R}$ & $\mathrm{R}$ & $\mathrm{R}$ & 10 & 9 & 8 & $\mathrm{R}$ & $\mathrm{R}$ & $\mathrm{R}$ & 15 & 10 & 10 & 10 & 10 & $\mathrm{R}$ \\
\hline $\begin{array}{l}\text { Penicillum } \\
\text { citrinum }\end{array}$ & $\mathrm{R}$ & $\mathrm{R}$ & $\mathrm{R}$ & $\mathrm{R}$ & $\mathrm{R}$ & $\mathrm{R}$ & 20 & 15 & $\mathrm{R}$ & $\mathrm{R}$ & $\mathrm{R}$ & $\mathrm{R}$ & 15 & 15 & 10 & 10 & $\mathrm{R}$ & $\mathrm{R}$ & 10 & $\mathrm{R}$ & $\mathrm{R}$ & $\mathrm{R}$ & $\mathrm{R}$ & $\mathrm{R}$ \\
\hline Absidia Sp. & $\mathrm{R}$ & $\mathrm{R}$ & $\mathrm{R}$ & $\mathrm{R}$ & $\mathrm{R}$ & $\mathrm{R}$ & 15 & 10 & 10 & $\mathrm{R}$ & $\mathrm{R}$ & $\mathrm{R}$ & $\mathrm{R}$ & $\mathrm{R}$ & $\mathrm{R}$ & $\mathrm{R}$ & $\mathrm{R}$ & $\mathrm{R}$ & $\mathrm{R}$ & $\mathrm{R}$ & $\mathrm{R}$ & $\mathrm{R}$ & $\mathrm{R}$ & $\mathrm{R}$ \\
\hline
\end{tabular}


Table 4 Mic's and Mfc's of the four selected plant (leaves) extract against 12 non dermatophyte Molds isolated from the study

\begin{tabular}{|c|c|c|c|c|c|c|c|c|}
\hline \multirow[t]{2}{*}{ Isolate } & \multicolumn{2}{|c|}{ Jatropha multifida } & \multicolumn{2}{|c|}{ Occimum gratissium } & \multicolumn{2}{|c|}{ Euphobia hirta } & \multicolumn{2}{|c|}{ Mitracarpus scaber } \\
\hline & $\begin{array}{l}\text { MIC } \\
(\mathrm{Mg} / \mathrm{ml})\end{array}$ & $\begin{array}{l}\text { MFC } \\
(\mathrm{Mg} / \mathrm{ml})\end{array}$ & $\begin{array}{l}\text { MIC } \\
(\mathrm{Mg} / \mathrm{ml})\end{array}$ & $\begin{array}{l}\text { MFC } \\
(\mathrm{Mg} / \mathrm{ml})\end{array}$ & $\begin{array}{l}\text { MIC } \\
(\mathrm{Mg} / \mathrm{ml})\end{array}$ & $\begin{array}{l}\text { MFC } \\
(\mathrm{Mg} / \mathrm{ml})\end{array}$ & $\begin{array}{l}\text { MIC } \\
(\mathrm{Mg} / \mathrm{ml})\end{array}$ & $\begin{array}{l}\text { MFC } \\
(\mathrm{Mg} / \mathrm{ml})\end{array}$ \\
\hline Fusarium solani & $>200$ & $>200$ & 100 & 200 & 100 & 200 & 25 & 50 \\
\hline Fusarium succisae & 200 & $>200$ & $>200$ & $>200$ & 200 & $>200$ & 50 & 100 \\
\hline Fusarium lichenicola & $>200$ & $>200$ & $>200$ & $>200$ & $>200$ & $>200$ & 25 & 50 \\
\hline Aspergillus flavus & $>200$ & $>200$ & 200 & $>200$ & 200 & $>200$ & 25 & 50 \\
\hline Aspergillus welwitschiae & $>200$ & $>200$ & 200 & $>200$ & 100 & 200 & 25 & 50 \\
\hline Aspergillus fumigatus & 200 & $>200$ & 100 & 200 & 100 & 200 & 50 & 100 \\
\hline Aspergillus aculeatus & $>200$ & $>200$ & 100 & 200 & $>200$ & $>200$ & 25 & 50 \\
\hline Clasdosporium tenuissimum & $>200$ & $>200$ & $>200$ & $>200$ & 100 & 200 & 50 & 100 \\
\hline Curularia kusanol & $>200$ & $>200$ & 100 & 200 & 50 & 100 & 25 & 50 \\
\hline Pestaloptiosis microspora & $>200$ & $>200$ & $>200$ & $>200$ & 25 & 50 & 50 & 100 \\
\hline Penicillum citrinum & 100 & 200 & 100 & 200 & 25 & 50 & 50 & 100 \\
\hline Absidia Sp. & $>200$ & $>200$ & 50 & 100 & 200 & $>200$ & $>200$ & $>200$ \\
\hline
\end{tabular}


The Methanolic extract of four plant leaves Euphorbia hirta, Occimum grastissium, Mitracarpus scaber and Jatropha multifida were subjected to phytochemical analysis. They were tested for eight different compounds. Result reveals presence and absence of these compounds at different concentrations respectively (Table 1). For Euphorbia hirta, qualitative analysis reveals abundance of glycosides, terpenoids, steroids and small concentration of flavonoid, alkaloid in wagner reagent and saponin while tannin and phenol were absent. The presence of flavonoids in this study is in agreement with analysis by [43]. Another work by [3] revealed presence of alkaloids, saponin, tannin, flavonoids, steroids and cardiac glycoside while terpeniod was absence when they carried out phytochemical analysis on Euphorbia hirta.

Occimum grastissium in this study reveals abundance of glycoside and terpenoid, presence of flavonoid, saponin, phenol, alkaloid with mayer and steroids while terpenoid was absent. This work agrees with other studies [34,44,45,46] while on the contrary, [47] in his study when he screened Occimum grastissium leaves flavoniod was absent while all other compounds were present.

Mitracarpus scaber in this study reveals abundance of glycoside, steroids, terpenoid, tannin and presence of flavoniod, saponin and alkaloid with mayer and wagner while phenol was absent. This result is also in agreement with study by [48] and [49] in their study phytochemical analysis of Mitracarpus scaber leaves reveals presence of alkaloids, tannin, cardiac glycosides and saponin. In another work by [50], the reverse was the case when he analysed the qualitative analysis of Mitracarpus scaber leaves, his result revealed abundance of saponin and flavoniod and presence of tannin, alkaloid, glycosides and steroids.

Jatropha multifida in this study reveals abundance of saponin and steroids, presence of glycosides, terpenoid, tannin, flavonoid, phenol, alkaloid with wagner while alkaloid was absent with mayer reagent. This is in accordance with a study by [51] and [52], in their work Jatropha multifida leaves revealed presence of alkaloid, tannin, saponin, flavonoid and phenol.

Quantitative phytochemical analysis of the total phenolic, flavonoid, tannin and alkaloid present in the plant leaves were determined by UV spectrophotometric method (Table 2). The total glycosidic compound were found to be in maximum quantity in Euphorbia hirta $(0.744 \mathrm{mg} / 100 \mathrm{~g})$, followed by Mitracarpus scaber $(0.660 \mathrm{mg} / 100 \mathrm{~g})$, Jatropha multifida $(0.510 \mathrm{mg} / 100 \mathrm{~g})$ and then Occimum gratissium $(0.232 \mathrm{mg} / 100 \mathrm{~g})$.The presence of this chemical compound in ascending order of plants extracts could be attributed to its potentiality of possessing antifungal properties. It is also an implication that Euphorbia hirta could possibly be a good producer of glycoside. Our analysis also reveals a high content of saponin (above $27.0 \mathrm{mg} / 100 \mathrm{~g}$ ) present in all the four plant leaves. Saponin have been known to posses antifungal, antiyeast and antibacterial properties. This study also revealed a trace amount of flavonoid ( -0.310 to $-2.040 \mathrm{mg} / 100 \mathrm{ml}) \mathrm{content}$ in all the four plant leaves. This is in disagrement with study by El-Mewafy [53], in their analysis methanolic extract of Jatropha multifida leaves contains significant amount of flavonoid $(38.22 \pm 3.26 \mathrm{mg} / 100 \mathrm{mg})$. Alkaloid compound in this study was observed to be maximum in Occimum gratissium leaves $(0.6122 \mathrm{mg} / 100 \mathrm{~g})$ than the other plant leaves extract $(\geq 0.35-0.40 \mathrm{mg} / 100 \mathrm{~g})$. Tannin content was observed to be in a very high amount in Euphorbia hirta $(0.1606 \mathrm{mg} / 100 \mathrm{~g})$ leaves than in the other plants $(0.02-0,05 \mathrm{mg} / 100 \mathrm{~g})$. Tannin has been known to posses antimicrobial activity. A study carried out by [54], showed that tannin extracted from plant inhibited spore formation of Aspergillus flavus and mycelia growth of Aspergillus niger. Our study also reveals presence of phenol although not in a very high content, amongst the plant leaves understudied in ascending order Mitracarpus scaber $(0.0127 \mathrm{mg} / 100 \mathrm{~g})$, followed by Occimum gratissium (0.0085), Jatropha multifida and Euphorbia hirta $(0.0023 \mathrm{mg} / 100 \mathrm{~g}$ ) respectively. This is in agreement with work by [51], when they analysed phytochemical compounds of Jatropha L species in their study phenol had the least concentration $(0.18 \%)$. This disagrees with [53], in their work methanolic extract of Jatropha multifida expressed highly significant content of phenol $(17.09 \pm 0.010 \mathrm{mg} / 100 \mathrm{~g})$.

Furthermore, methanolic extract of these four plant leaves Uatropha multifida, Occimum grastissimum, Euphorbia hirta and Mitracarpus scaber) were subjected to antifungal sensitivity test employing the disc diffusion method. Twelve fungal species of the non-dermatophytic molds were tested belonging to Absidia spp., Fusarium solani, Fusarium succisae, Fusarium lichenicola, Aspergillus flavus, Aspergillus welwitschiae, Aspergillus fumigatus, Aspergillus aculeatus, Curvularia kusanol, Pestalotiopsis microspora, Cladosporium tenuissimum and Penicillum citrinum (Table 3 and 4). Results revealed that all isolates were resistant to Jatropha multifida in-vitro at all concentrations except for Fusarium solani that was found to be weakly sensitive which could be attributed as resistant mutant (RM) at $200 \mathrm{mg} / \mathrm{ml}$ with an inhibition zone (IZ) of $15 \mathrm{~mm}$. To strengthen this, minimum inhibitory concentration(MIC) (Table 4) was carried out using tube dilution method and subculturing of the relative sample and results showed that most isolates had their MIC at concentration $>200 \mathrm{mg} / \mathrm{ml}$ except Penicillum citrinum that expressed its MIC at a concentration of $\geq 100 \mathrm{mg} / \mathrm{ml}$ and minimum fungicidal concentration (MFC) at $200 \mathrm{mg} / \mathrm{ml}$, while Aspergillus fumigatus and Fusarium succisae showed its MIC at $200 \mathrm{mg} / \mathrm{ml}$ and MFC $>200 \mathrm{mg} / \mathrm{ml}$ respectively. This could be attributed to antimicrobial potentials of Jatropha 
multifida leaves. A study by [55] stated that methanolic extract of Jatropha multifida leaves inhibited growth of fungus at an MIC of $25 \mu \mathrm{g} / \mathrm{L}$.

From our results Occimum grastissimum leaves extract were sensitive on Fusarium linchenicola $(200 \mathrm{mg} / \mathrm{ml})$, Aspergillus flavus $(200 \mathrm{mg} / \mathrm{ml})$, Aspergillus welwitschiae $(200 \mathrm{mg} / \mathrm{ml})$, Aspergillus fumigatus $(25-200 \mathrm{mg} / \mathrm{ml})$, Aspergillus aculeatus $(100 \mathrm{mg} / \mathrm{ml})$, Curvularia kusanol $(25-200 \mathrm{mg} / \mathrm{ml})$, Penicillum citrinum $(100 \mathrm{mg} / \mathrm{ml})$ and Absidia spp. $(50-200 \mathrm{mg} / \mathrm{ml})$ with inhibition zones (IZ) ranging from 5mm-20mm and was resistance on Fusarium solani, Pestalotiopsis microspora, Cladosporium tenuissimum and Fusarium succisae at all concentrations. Afterwards the MIC was also carried out on the isolates and results revealed that Penicillum citrinum, Aspergillus aculeatus, Aspergillus fumigatus, Curvularia kusanol and Absidia spp. had MIC at $100 \mathrm{mg} / \mathrm{ml}$ and MFC at $\geq 200 \mathrm{mg} / \mathrm{ml}$ while Aspergillus welwitschiae had a MIC at $200 \mathrm{mg} / \mathrm{ml}$ and MFC $>200 \mathrm{mg} / \mathrm{ml}$. This result is an indication that Occimum grastissimum possess strong antifungal potentials.This is in agreement with previous works by [34] in their work antimicrobial activities of leaves of Occimum grastissimum were observed. Another study by [47] supports that Occimum grastissium leaves posseses antifungal properties. In yet another study by [56] revealed that Occimum grastissium leaves extract at higher concentration did not support growth of fungi (Absidia blakslseeana, Macrophomina phareolina and Fusarium solani).

Also methanolic extract of Euphorbia hirta leaves were tested for antifungal effects on the isolates and results revealed that the extract were sensitive to Fusarium solani, Fusarium succisae, Aspergillus flavus, Aspergillus weiwitschiae, Aspergillus fumigatus, Cladosporium tenuissimum, Curvularia kusanol, Pestalotiopsis microspora and Penicillum citrinum at $200 \mathrm{mg} / \mathrm{ml}$ with inhibition zones (IZ) ranging from $10 \mathrm{~mm}-20 \mathrm{~mm}$ and resistance to 3 (Absidia spp., Fusarium lichenicola and Aspergillus welwitschiae). To strengthen this MIC of the extract was carried out and it was observed that the 3 isolates that were resistance had their MIC at concentrations above $200 \mathrm{mg} / \mathrm{ml}$ others that were sensitive had their MIC at concentration $\geq 200 \mathrm{mg} / \mathrm{ml}$ except Pestalotiopsis microspora that had its MIC at concentration $\geq 50 \mathrm{mg} / \mathrm{ml}$ and MFC at concentration $\geq 100 \mathrm{mg} / \mathrm{ml}$ while Penicillum citrinum had its MIC at concentration $\geq 25 \mathrm{mg} / \mathrm{ml}$ and its MFC at concentration $\geq 100 \mathrm{mg} / \mathrm{ml}$. This is an indication that methanolic extract of Euphorbia hirta leaves posses antifungal quality and this can be attributed to presence of active ingredients present in the leaves extract. This is not in accordance with a work by [57] in their study it was observed that ethanolic extract of Euphorbia hirta (leaves) showed no antifungal activity on Aspergillus fumigatus and Aspergillus niger using dics diffusion method while on the contrary [58] in their study also agrees with our study that leaf extracts of Euhorbiaceae posses growth inhibition against fruit rot fungi.

Methanolic extract of Mitracarpus scaber leaves were tested for antifungal sensitivity on the isolates using disc diffusion method and results revealed that the extract were sensitive to Fusarium linchenicola, Aspergillus aculeatus, Cladosporium tenuissimum, Curvularia kusanol and Penicillum citrinum at $200 \mathrm{mg} / \mathrm{ml}$ with inhibition zones (IZ) ranging from $10 \mathrm{~mm}-15 \mathrm{~mm}$. On Aspergillus flavus and Aspergillus welwitschiae sensitivity was at $100 \mathrm{mg} / \mathrm{ml}$ with IZ of $10 \mathrm{~mm}$ while Aspergillus fumigatus showed sensitivity at $50 \mathrm{mg} / \mathrm{ml}$ with IZ of $5 \mathrm{~mm}$ and Pestalotiopsis microspora had sensitivity at $12.5 \mathrm{mg} / \mathrm{ml}$ with IZ of $10 \mathrm{~mm}$. Three of the isolates (Absidia spp., Fusarium succisae and Fusarium solani) were resistant to this extract. Minimum inhibitory concentration (MIC) on these isolates using tube dilution method and subculturing of the samples revealed Aspergillus aculeatus, Aspergillus welwitschiae, Aspergillus flavus, Curvularia kusanol and Fusarium lichenicola was at $25 \mathrm{mg} / \mathrm{ml}$ and minimum fungicidal concentration (MFC) at $\geq 50 \mathrm{mg} / \mathrm{ml}$. Penicillum citrinum, Aspergillus fumigatus, Fusarium succisae, Cladosporium tenuissimum, Pestalotiopsis microspora and Fusarium solani had their MIC at $50 \mathrm{mg} / \mathrm{ml}$ and MFC at $>100 \mathrm{mg} / \mathrm{ml}$, while Absidia spp. had both MIC and MFC $>200 \mathrm{mg} / \mathrm{ml}$. This is an indication that Mitracarpus scaber posses very strong antifungal potentials which can be attributed to possession of active compounds. This agrees with work by [6] in their study antimicrobial activity of Mitracarpus scaber "zucc" were analysed on agar plates and concentration ranging between $25 \mathrm{mg} / \mathrm{ml}$ and $300 \mathrm{mg} / \mathrm{ml}$ were used to evaluate minimum inhibitory concentration (MIC). From their results it was observed that fungal isolates such as Candida albicans had MIC at $75 \mathrm{mg} / \mathrm{ml}$. Another study by [9] analysed the efficacy of ethanolic extract of Mitracarpus scaber against fungal isolates ( mould and yeast) and results revealed that clinical isolates showed sensitivity at $50 \mu \mathrm{g} / \mathrm{ml}^{-1}$. According to [59] in their work Mitracarpus scaber expressed antifungal activity against Aspergillus flavus, Microsporum canis, Candida albicans with MIC and MFC $<65 \mu \mathrm{g} / \mathrm{ml}$. This is in accordance with our study.

\section{Conclusion}

This study has revealed that these plants leaf extracts evaluated contains active compounds that can be used as alternative medicines in the treatment of infections caused by fungal isolates. The extract of Mitracarpus scaber showed the highest antifungal activity against the non dermatophytic molds followed by Euphorbia hirta, Occimum grastissum and Jatropha multifida. This is an indication that these our indigenous plants studied could be harnessed and used in the production of antifungal drugs. Further investigation will be to identify the particular active compounds that might be responsible for these antifungal activities. 


\section{Compliance with ethical standards}

\section{Acknowledgments}

I sincerely acknowledge the help of the Veterinary doctors in charge of the cattle market in both Abia and Imo state. The entire staff of the College of Pharmacy, Igbinedion University Okada for their Assistance offered to this research in their Laboratory. Also my gratitude goes to Prof. Tetfeng of Niger Delta University for his assistance in the Biotechnology analysis of this research.

\section{Disclosure of conflict of interest}

All authors declared that there is no conflict of interest.

\section{Statement of ethical approval}

Based on the compliance of the ethical standard of Imo and Abia State in Nigeria. The Ethical permit No; NAR/Vet/XX of the Ministry of Agriculture and Natural Resources Owerri, Imo state dated $13^{\text {th }}$ March, 2017 and that of the Ministry of Agriculture Umuahia, Abia state Ref. No; DVS/01/RCH/01/18, dated $4^{\text {th }}$ June, 2018, was also issued before the commencement of the screening of the cattles in both States

\section{References}

[1] Gini TG, Jothi Jeya G. In vitro screening of antibacterial and antifungal activity of Marsileaquadrifolia (Marsileaceae) Linn. Extract. American Journal of Phytomedicine and Therapeutics. 2015; 3(4): 313 - 329.

[2] Falodun A. Herbal medicine in Africa-distribution, standardization and prospects. Research Journal of Phytochemistry. 2010; 4(3): 154-161.

[3] Amir Muhammad Khan, Rizwana Aleem Qureshi, Faizan Ullah, Syed Aneel Gilani, Asia Nosheen, Sumaira Sahreen, Muhammad Khan Laghari, Shafia-Ur- Rehman, Ishtiag Hussain, Waheed Murad. Phytochemical analysis of medicinal plants of Margalla Hills and surroundings. Journal of Medicinalplants Research. 2011; 5(25): 60176023.

[4] Jachak SM, Saklani A. Challenges and opportunities in drug discovery from plants. Journal of current science. 2007; 92(1): 1251-125.

[5] Michael Niyi Aransiola, Charele Ehikhase, Joy C. Mmegwa, Idris Olayinka Wahab. Microbiology: A systems approach by Majorie Kelly Cowan and Kathleen Park Talaro.Published by Mc Graw Hill.1 st Edition Newyork,America. 2006; 131-139.

[6] Abere TA, Onyekweli AO, Ukoh GC. In vitro Antimicrobial activity of the extract of Mitracarpus Scaber leaves formulated as syrup. Tropical Journal of Pharmaceutical Research. 2007; 6(1): 679-682.

[7] Hemandez NE, Tereschuk ML, Abdala LR. Antimicrobial activity of flavonoid in medicinal plants from tatidel valle (Tacuman, Argentina). Journal of Ethanopharmacol. 2000; 73(1-2): 317-322.

[8] Karaye P. Gloria, Dogo GI. Abraham, Karaye Kuduk. Evaluation of antimycotic activity of crude methanolic extract of mitrocarpus scaber on candida albicans and Trichophyton mentagrophytes. Saudi Journal of medical and pharmaceutical Sciences. 2017; 3(3): 217-220.

[9] Anejionu Miriam Goodness, Nweze Emeka Innocent, Dibua Esther Uju, Esimone Charles Okechukwu. Efficacy of two commonly used antifungal Herbs in Nigeria against Clinical isolates of Fungi. Microbiology Journal. 2012; 2(3): 70-8.

[10] Thes PM, Soumahoro IA, Ackah JA, Zirihi GN, Djaman AJ. Action du savon misca-mates dans le trairement des teignes. Phytotherapie. 2011; 9(6): $354-358$.

[11] Kumar A, Sharma S. An evaluation of multipurpose of seed crop for industrial uses (Jatropha curcas). A review Bios Eng . 2008; 97: 201-207.

[12] Martinez-Herrara J, Siddhuraju P, Francis G, Davila-Ortiz G, Becker K. Chemical composition toxic/antimetabolic constituents and effects of different treatments on their levels in four provenances of Jatropha curcas L. from Mexico. Food Chem. 2006; 96: 80-89. 
[13] Reddy Prasad DM., Amirah Izam, Maksudur Rahman Khan Md. Jatropha curcas: plants ofmedicinal benefits. Journal of Medicinal Plants Research. 2012; 6(14): 2691 - 2699.

[14] Rakshit K Devapapa, Harinder PS Makkar, Klaus Becker. Jatropha toxicity - A Review Journal of Toxicology and Environmental Health. 2010; 13(6): 476-507.

[15] Jati Batoro, Dian Siswanto. Ethno Medicina; survey of plants used by local society in Poncokusumo district Malang, East Java Province, Indonesia, Asian Journal Medical Biological Research . 2017; 3(2): 158-167.

[16] Wongsatit Chuakul. Medicinal plants in the Khok Pho District, Pattani Province (Thailand) The Journal of Phytopharmacy. 2005; 12(2): 23-45.

[17] Olapeju Aiyelagbe, Bola J. Oguntuase, Babatunde D. Arimah, Bolanle A. Adeniyi. The antimicrobial activity of Jatropha multifida extracts and chromatographic fractions against sexually transmitted infections. Journal of Medical Sciences (Faisalabad). 2008; 8(2): 143-147.

[18] Matasyoh LG, JC Matasyoh, FN wachira, MG Kinyua, AW Thairu Muigai, TK Mukiama. Chemical composition and antimicrobial activity of the essential oil of Ocimum grastissimum leaves groeing in Eastern Kenya. African Journal of Biotechnology. 2007; 6(6): 760-765.

[19] Koche DK, Kokate PS, Suradkar SS and Bhadange DG. Prelimanry Phytochemistry and Antibacterial Activity of ethanolic Extract of Ocimum Gratissimum Leaves. Bioscience Discovery. 2012; 3(1): 20-24.

[20] Mbakwem-Aniebo C, Onianwa O, Okonko IO. Effects of Ocimum Gratissimum Leaves on common dermatophytes and causative agent of pityriasis versicolor in Rivers State, Nigeria. Journal of Microbiology Research. 2012; 2(4): 108-113.

[21] Nwinyi OC, Chinedu NS, Ajani OO, Ikpo CO, Ogunniran KO. Antibacterial effects of extracts of Ocimum gratissimum and piper guineense on Escherichia coli and Staphylococcus aureus. African Journal of Food Science. 2009; 3(3): 077-081.

[22] Nweze EL, Eze EE. Justification for the use of Ocimum gratissimum in herbal medicine and its interaction with disc antibiotics. BMC complementary and Alternative medicine. 2009; 9(37): 1-6.

[23] Ijeh II, Njoku OU, Ekenza EC. Medicinal Evaluation of xylopia aethiopica and Ocimum gratissimum. Journal of medicinal Aromatis Science. 2004; 26(1): 44-48.

[24] Ladipo MK, Doherty VF, Kanife UC. Phytochemical Screening and antibacterial investigation of the extract of Ocimum gratissimum (Scent Leaf) on selected Enterobacteriaceae. Production agriculture and technology. 2010; 6(2): 75-84.

[25] Silva MRR, Oliveria Jr, Fernandes OFL, Passos XS, Costa CR, Souza LKH, Lemos JA, Paula JR. Antifungal activity of Occimum gratissimum towards dermatophytes. Mycoses. 2005; 48(3): 172 - 175.

[26] Chitra M, Muga V, Sasikumar Dhanarasu, Awdah Masoud Al-hazimi. Screening of phytochemical and In-vitro activity of Euphorbia hirta L. Journal of chemical pharmaceutical Research. 2011; 3(6): 110-114.

[27] Juveriyah Kausar, Durai Muthumani, Agaath Hedina, Sivasamy, Vijaya Anand. Review of the phytochemical and pharmacological activities of Euphorbia hirta Linn. Pharmacognosy Journal. 2016; 8(4): 310-313.

[28] Huang Linfang, Chen Shillin, Yang Melhua. Euphorbia hirta (Feiyangcao): A review on its ethnopharmacology, phytochemistry and pharmacology. Journal of Medicinal Plants Research. 2012; 6(39): 5176-5185.

[29] Saravanan R, Dhachinamoorthi D, Senthilkumar K, Srilakshmi M, Sri Divya T. Antibacterial activity of Euphorbia hirta extracts. International Journal of Research in Ayurveda and Pharmacy. 2012; 3(3): 439-441.

[30] Rajah Mohammad Abu Basma, Zuraini Zakaria, Sasidharan Sreenivasan, Latha Lachimanan. Assessment of Euphobia hirta L. Leaf, Flower, stem and Root Extract for their antibacterial and antifungal activity and Brine shrimp lethality. Molecules. 2010; 15: 6008-6018.

[31] Singh Geeta, Kumar Padma. Extraction and antimicrobial activity of alkaloids of Euphorbia hirta. Journal of Pharmacy Research. 2011; 4(4): 1228-1230.

[32] Tabassum Nahida, Hamdani Mariya. Plants used to treat skin diseases. Pharmacognosy Review. 2014; 8(15): 5260.

[33] Mbata TI, Duru MC, Onwumelu HA. Antibacterial activity of crude seed extracts of Buchholzia coriacea E. on some pathogenic bacteria. Journal of Dev.Bio and Tissue Engr. 2009; 1(1): 001-005. 
[34] Ameh GI. Evaluation of the phytochemical composition and antibacterial properties of crude methanolic extract of leaves of Ocimum gratissimum. J. Nat. Sci. Engr. Tech. 2010; 9(1): 147-152.

[35] Harbornen JB. Phytochemical methods: A guide to modern technique in plant analysis.(3rd ed). London: Chapman and Hall. 1998.

[36] Khandelwal KR. Pratical pharmacognosy, Techniques and Experimentals.16 $6^{\text {th }}$ Edn.,Nirali Prakashan,Pune,India,ISBN:81-85790-30-2. 2006; 107.

[37] Sofowora A. Medicinal plants and Traditional Medicinal in Africa, $2^{\text {nd }}$ Ed. Sunshine House, Ibadan,Nigeria: Spectrum Books Ltd: screening plants for Bioactive Agents. 1993; 134-156.

[38] Trease GE, Evans WC. Pharmacology (12 ${ }^{\text {th }}$ ed). Bailliere Tindal:London. 1983.

[39] Harborne JB. Methods of plant analysis. In phytochemical Methods Chapman and Hall, London.1973.

[40] Bohn BA, Kocipai- Abyazan R. Flavonoid and condensed tannins from the leaves of vaccinum raticulation and Vaccinum calcyimium. Pacific Science. 1994; 48: 458 -463.

[41] Polshettiwar SA, Ganjiwale RO, Wadher SJ, Yeole PG. Spectrophotmetric estimation of total tannins in some Ayurvedic eye drops. Indian Journal of pharmacological Science. 2007; 69: 574 -576.

[42] Clinical and laboratory Standard Institute (2008). Specimen handling and processing Speciality Collection (CLSI.).

[43] Geeta Singh and Padma Kumar. Phytochemical study and screening for antimicrobial activity of flavonoids of Euphorbia hirta. International journal of applied basic medicinal research. 2013; 3(2): 111-116.

[44] Afolabi Clement Akinmoladun, Emmanuel Afor Efere Martins Obuofor. Phytochemical constituent and antioxidant activity of extract from leaves of Occimum grastissium. Scientific research and essays. 2007; 2(5): 163166.

[45] Gupta VK, Singh J, Kumar R, Bhanot A. Pharmacognostic and preliminary phytochemical study of Occimum gratissium Linn ( Family;lamiaceae). Asian journal of plant sciences. 2011; 10: 365-369.

[46] Pricilla, Alexander. Phytochemical screening and mineral composition of the leaves of Occimum grastissium (scent leaves). International journal of applied sciences and biotechnology. 2016; 4(2): 161-165.

[47] Orji JO, Nwuzo AC, Ejikeugwu PC, Ugdo EN, Moses IB, Nwakaeze EA, Nwankwo CP. Antifungal activities of Occimum gratissimum and Gongronema latifolium leaves on colletotrichym species isolated from spoilt tomatoes. International Journal of Pharmaceutical Science invention. 2015; 4(5): 42 - 45.

[48] Chilaka KC, Unekwe PC, Enyi JC, Ogamba JO. Evaluation of antimicrobial properties of methanol extract of Mitracarpus scaber leaves. Tropical journal of medical research. 2009; 13(2): 10-15.

[49] Ouadja B, Anani K, Djrei B, Ameyapoh YO, Karou DS. Evaluation of the phytochemical composition, antimicrobial and antiradical activites of Mitracarpus scaber (Rubiaceae). Journal of medicinal plants Research. 2018; 12(28): 493-499.

[50] Shinkafi SA. Antidermatophytic activities, phytochemical screening and chromatographic studies of Pergularia tomentosa L. and Mitracarpus scaber zucc.( Leaves) used in the treatment of dermatophytoses. International Journal of Microbiology. 2013; 4(1): 29-37.

[51] Nwokocha A, Blessing IO. Agbagwa, BE Okoli. Comparative phytochemical screening of Jatropha L.species in the Niger Delta. Researh journal of phytochemistry. 2011; 5: 107-114.

[52] Sallykutty Thomas. Pharmacognostic and phytochemical constituents of leaves of Jatropha multifida Linn and Jatropha podagrica Hook. Journal of pharmacognosy and phytochemistry. 2016; 5(2): 243-246.

[53] El-Mewafy Abdou, El Mewafy El Ghadban, Omneya Farouk Abou El- leel, Ehab MB Mahdy. Morphological phytochemical and molecular characterization on some Jatropha species cultivated in Egypt. International Journal of Pharmaceutical Science and Scientific Research. 2016; 3(1): 1-13.

[54] Nouioua Wafa, Gaamoune Sofiane, Kaabache Mouhamed. The antioxidant and antimicrobial activities of flavonoids and tannins extracted from Phlomis bovei De Noe. European Journal of Experimental Biology. 2016; 6(3): 55-61.

[55] Sillma Rampadarath, Daneshwar Puchooa and Mala Ranghoo Sanmukhiya. Antimicrobial, phytochemical and insecticidial properties of Jatropha species and Wild Ricinus Commnunis I found in Mauritius. International Journal of Pharmacognosy and Phytochemical Research. 2014; 6(4): 831 - 840. 
[56] Adekunle AA, Uma UN. Effect of benlate solution,crude leaf extract of Azadirachta indica and Occimum gratissimum on growth of fungi and preservation of melon seeds. Plant pathology Journal. 2005; 4(1): 29 -34.

[57] Waseem Ahmad, Shilpa Singh, Sanjay Kumar. Phytochemical screening and antimicrobial study of Euphorbia hirta extracts. Journal of medicinal plants studies. 2017; 5(2): 183 - 186.

[58] Ilondu EM, Bosah BO. Growth inhibition potentials of leaves extract from four selected Euphorbiaceae against fruit rot fungi of Africa star apple (Chrysophyllum albidun GDon). Journal plant pathology and microbiology. 2015; 6(9): $1-6$.

[59] Cimanga RK, Kambu KL, Tona Bruyne, Dea T, Sandara A, Jotte T, Pietera L, Vlietinck AJ. Antibacterial and antifungal activities of some extracts and fractions of Mitracarpus scaber zucc (Rubiaceae). Journal of natural remedies. 2004; 4(1): 17 - 25. 